UDC 81'246.2:81'25(045)

DOI https://doi.org/10.32838/2663-6069/2019.3-2/11

Nechyporenko $V_{0}$ O.

Vinnytsia Institute of Trade and Economics

of Kyiv National University of Trade and Economics

\title{
IDENTITIES OF BILINGUAL AUTHORS
}

The article analyses the problem of a bilingual writer identity and creativity. A bilingual person's language processes is the core issue of studies caused by the individual's growing role in the situation of intensive and extensive cross-cultural communication. Research on bilingualism contributes to theorizing in other disciplines (e.g. linguistics, sociology, psychology, neurology, pedagogy) and related fields (e.g. language acquisition, speech processing). The last decades have demonstrated the growing interest to the studying of the bilingual identity; the in-depth integrative comprehension of the phenomenon of bilingualism is recognized as the key approach in today's linguistic studies. The scientific research of individual (literary) bilingualism and the problem of identity as rare and understudied phenomenon seems to be important and relevant. The aim of the article is to describe the problem of bilingual identity, to highlights the relationship between language and identity.

Language and identity are closely related concepts and they are of particular importance when discussing bilingual writers' identities. The metaphors 'language as a symbolic resource' and 'language as a badge of identity' have been discussed in the article. The author share the opinion of scholars (J. Cummins, B. N. Pierce) that language learning and then the (self)translation practice is more than a process of encoding and decoding language; bilingual practice is intertwined with identity engagement, investment and negotiation.

Various reasons for authors to become bilingual are mentioned. Successful writing and selftranslation experience of some bilingual authors is discussed. A bilingual author is not merely a sum of two complete or incomplete monolinguals but rather a unique and specific linguistic and cultural configuration.

The research of literary bilingualism makes it possible to contact indirectly with phenomenon of a bilingual writer's language consciousness, to trace the patterns of its development and functioning, and to study literary bilingualism as socio- and psycholinguistic phenomenon, as a marker of deep language contacts. The article defines future trends in scientific development of this problem.

Key words: bilingual authors, language, identity, creativity, self-translation, literary translingualism.

Introduction. In the $21^{\text {st }}$ century linguistic studies aimed at researching language as a means of communication have been replaced by works which describe and analyze an individual as a subject of communication. A bilingual person's language processes is the core issue of studies caused by the individual's growing role in the situation of intensive and extensive cross-cultural communication. Today, because of globalization, migration routes, exiles, personal choices, more and more people speak a second language. Individual and societal bilingualism are neither recent nor temporary phenomena. Bilingualism is not exceptional but more frequent than might be commonly thought. To be bilingual or multilingual is not the aberration supposed by many; it is, rather, a normal and unremarkable necessity for the majority in the world today. Furthermore the number of bi- and multilingual speakers a country produces may be seen as an indicator of its educational standards, economic competitiveness and cultural vibrancy. Clearly, bilingualism may be a condition to be aspired to and cherished, rather than one to be prevented or remedied.

The topicality of the article. Current research on bilingualism is motivated by various concerns. The monolingual mindset as a background for multiple studies on such an extraordinary phenomenon as bilingualism is not a norm any more. Nowadays it is often claimed that, globally, multilingualism might be more widespread and mundane than monolingualism. The authors of "Bilingualism: Beyond Basic Principles" underline that the prevalence of bilingualism as an individual and societal state, and the advantages it is thought to bestow, need further documenting, as do reactions to it from all quarters. Its study has practical applicability (e.g. for speech pathology, education, communication technology) as well as general theoretical utility. Research on bilingualism contributes to theorizing in other disciplines 
(e.g. linguistics, sociology, psychology, neurology, pedagogy) and related fields (e.g. language acquisition, speech processing). General theories of the human mind, language and behavior must ultimately incorporate the basic facts of bilingualism if they are to be comprehensive and viable [1, p. 2-3].

The previous studies. As a phenomenon bilingualism has a long and reach history dating for more than two thousand years and continues to be widespread in different cultures. The tradition of the bilingual writer creating a single text in two languages, smoothly spanning different audiences, is a rich and venerable one, arising in Greco-Roman antiquity and thriving in the European Middle Ages and Renaissance. Self-translation was a common practice in the ambient translingual world of early modern Europe, when bilingualism was the norm, and writers increasingly translated between Latin and vernaculars. For centuries it has been practiced by many men of letters such as Leonardo Bruni, Etienne Dolet, Thomas More, James Joyce, Samuel Beckett, Vladimir Nabokov, Chyngyz Aitmatov, Elsa Triolet, Andrei Makine and others. Bilingual writers become bilingual for varied reasons. Xuemei Li highlights the most widespread of them: some are born into a country that has two or more official languages or a good foreign language education system; some live in a multiethnic family in which members speak different languages and learning more than one language is a natural painless acquisition; others become bilingual because their family language is different from the majority language of the society. There are yet others who have to earn the bilingual status as a result of crossing national borders, either voluntary or involuntary [4, p. 259].

Literary bilingualism has not been ignored by linguists. Scientific works of V. Vinogradov, B. Larin, Yu. Lotman, A. Potebnia, L. Scherba contain a lot of valuable comments and conclusions. The problem of switching from one language to another and creation of full-fledged literary works written on non-native languages has been successfully highlighted by literary theorists. Among them are Bernard Binlin Dadie, R. Danilevskiy, Yu. Levin, M. Ryzhova and others. Should be also mentioned authors who made the attempt to study literary bilingualism manifested in self-translation practice: I. Permiakova, A. Finkel. Different aspects of bilingualism were discussed in scientific theses of K. Baleyevskikh, M. Kirienko, S. Nikolayev.

The last decades have demonstrated the growing interest to the studying of the bilingual identity; the in-depth integrative comprehension of the phenomenon of bilingualism is recognized as the key approach in today's linguistic studies (G. Vishnevskaya, S. Nikolayev, A. Shirin and others). Such comprehension should be based on the latest linguistics achievements and be implemented at the junction of the related sciences: sociology, cognitology, pragmatics, psychology, translation studies, and theory of communication. Translated works of fiction literature and bilingual authors' works take a significant place in the world culture, but the scientific research of individual (literary) bilingualism and self-translation practice as rare and understudies phenomenon seems to be important and relevant.

The aim of the article is to describe the problem of bilingual identity, to highlights the relationship between language and identity.

Discussion. Many studies try to answer the question: What is the bilingual text? The most common answer is: "the bilingual text is a self-translation, authored by a writer who can compose in different languages and who translates his or her texts from one language into another" $[3$, p. 1]. There is no doubt that literary bilingualism of any writer positively influences his or her creative work. The situation of bilingualism gives the possibility to see an ambivalent role of the language in the literary creation. But it is still the question, sounded by R. Federman, the French-American writer: I have often wondered, as a bilingual writer and a self-translator, whether I am blessed because of this phenomenon or cursed because of it [2]?

Linguists define bilingualism in many different ways. You are bilingual according to origin, if you have learned two languages in your family from your parents and have used two languages from the beginning of your life; according to language proficiency if you have come into contact with two languages and master two languages completely or equally well; according to language function if you can alternate between two languages in most situations according to your own choice and the demands of society; according to attitudes if you feel yourself to be bilingual and are identified as bilingual by others [6].

The traditional analyses of bilingual texts are concentrated on "gaps" between texts, languages, and cultures. One must start from a point closer to the common core of the bilingual text, that is, within the textual intersections and overlaps of versions. Real translators live and work not in a hypothetical gap between languages, between source and target cultures, but in the midst of them; they combine several languages and cultural competencies at once, and constitute a mid-zone of overlaps and intersections, being actively engaged in several cultures simultaneously. Hence every translator is 
“a minimal interculture". In R. Federman's opinion the bilingual writer allows his readers (if he has any) to listen to the dialogue which he entertains within himself in two languages, even though in most cases the readers (who are usually not bilingual) only hear half of this internal (one should almost says infernal) dialogue [2]. Explaining his practice of self-translation R. Federman notes: Usually when I finish a novel <..>, I am immediately tempted to write (rewrite, adapt, transform, transact, transcreate - I am not sure what term I should use here, but certainly not translate) the original into the other language. Even though finished, the book feels unfinished if it does not exist in the other language [2].

An interesting research approach demonstrates Xuemei Li in her work "Souls in Exile: Identities of Bilingual Writers" [4]. The author discusses two groups of bilingual writers: the global souls (those who either claim to be or may be considered to be), and the souls in exile (either voluntary or involuntary). The former are the writers who are raised in multicultural environments and feel comfortable to traverse linguistic and geographic borders, such as Federman, Iyer; the latter are bilingual writers who are forced by circumstances to write in their second/ additional language, which is far from the sounds of home and childhood and origin, and have to alternate their feelings and identities while switching languages, including Dorfman, Hoffman, Lvovich.

Language and identity are closely related concepts and they are of particular importance when discussing bilingual writers' identities. The metaphors 'language as a symbolic resource' and 'language as a badge of identity' best capture the characteristics of their interconnections. Xuemei Li, basing her theory on the works of Carter and Heller, underlines that language is not a neutral entity; instead, it is always associated with certain texts and contexts that are determined by social and sociocultural factors. There are different symbolic sources in a society, among which are linguistic resources represented by and through language. Then language is a kind of password. If you understand the language responsively and are able to manipulate it, you pass; if you have access to the more highly valued form of that language, you gain a more prestigious identity. In other words, to construct an identity that allows access, you need to master the language first [4, p. 262].

Some scholars, including linguists and educators focusing on first and second language development, view language learning and then the (self)translation practice as more than a process of encoding and decoding language; rather they view bilingual practice as intertwined with identity engagement, investment and negotiation (J. Cummins, B. N. Pierce).

The theoretical framework adopted in the present study is best justified in A. Pavlenko's work "In the world of the tradition I was unimagined": Negotiation of identities in cross-cultural autobiographies" where the author uses the terms postculturalism, postmodernism, or critical inquiry, interchangeably emphasizing similarities which they all share [5, p. 318]. Of particular importance to us is the postmodernism focus on language as the locus of social organization, power and individual consciousness, and as a form of symbolic capital. Learning, in turn, will be seen as socialization, or a situated process of participation in particular communities of practice, which may entail the negotiation of ways of being a person in that context. Thus, "because learning transforms whowe are and what we can do, it is an experience of identity" [7, p. 215], a process of becoming, or avoiding becoming a certain person, rather than a simple accumulation of skills and knowledge. As the scholar underlines, in accordance with Wenger's theory, identities will be seen not simply as discursively constructed categories of self but as lived experiences of participation in specific communities, where meanings of particular positions, narratives and categories must be worked out in practice [5, p. 319]. At the center of a poststructuralist theory of second language acquisition are the view of language as symbolic capital and the site of identity construction, the view of language acquisition as language socialization and the view of L2 users as agents whose multiple identities are dynamic and flexible. Norton points out, the process of engagement with and participation in new communities of practice where certain identities may be rendered inaudible, may lead to development of new identities, or subject positions, in order to gain a voice and "the power to impose reception" [cit. in 5, p. 319]. A. Pavlenko underlines, that first of all, L2 users' linguistic, social, cultural, gender, racial, and ethnic identities mediate their access to linguistic resources and interactional opportunities available in the L2. Secondly, theiragencies and investments in language learning and use are shaped by the range of identities available for them in the L2. At times, the L2 discourse available to L2 users may provide them with unique means of self-representation that prompt them to cross boundaries and assimilate to the new communities or to become members of multiple communities. In other contexts, L2 users or bi- and multilinguals may opt for constructing new and mixed linguistic identities [5, p. 319].

Writing is often considered a conscious and thoughtful reflection of the author's life and attitudes. 
Writers could write in their second language for various reasons. Some are compelled to do so as victims of political upheavals, and writing in the additional language seems to offer a protection to them. Others find comforts and liberation by expressing themselves in the language they choose to use. As Xuemei Li says, "To them writing in an additional language is like flipping out another badge of identity" [4, p. 263]. In this case, some notes made by bilingual authors seem to be interesting and useful for the future identity analysis. Hungarian-born poet George Szirtes writes both English and his native tongue. He confesses that a second language always retains its brilliant, opiate character, especially if you are a poet whose every perception and process is articulated through it: voluptuousness, thick glass, poppies, opiates... That may or may not be true. But there you are, with the exquisite zoology of both languages, slightly detached from the soil you tread on, and may be you see some things that the soil-born cannot. Maybe you can see them at certain angles. And you can make a certain poetry out of this, if only because poetry only appears at the point at which language is both familiar and strange [6].

Almost the same position we observe in Federman's attitude. He claimed: "Language is what gets us where we want to go but at the same time prevents us from getting there $\langle\ldots\rangle$ then by using another language $<\ldots>$ we may have a better chance of getting where we want to go, a better chance of saying what we wanted to say, or at least we have a second chance of succeeding [2].

Some scholars discount achievements of a significant body of L2 users, positioning even bilingual writers as deficient and incompetent speakers. Thus Steven Pinker wrote: "Even the adults who succeed at grammar often depend on the conscious exercise of their considerable intellects, unlike children, to whom language acquisition just happens. Vladimir Nabokov, another brilliant writer in English, refused to lecture or be interviewed extemporaneously, insisting on writing out every word beforehand with the help of dictionaries and grammars. As he modestly explained, "I think like a genius, I write like a distinguished author, and I speak like a child" [cit. in 5, p. 326]. We can't share Pinker's opinion. V. Nabokov read and wrote Russian, English and French by the time he was seven, as he said he had "a perfectly normal trilingual childhood". Growing up trilingual in Saint Petersburg, with Russian parents and French and English governesses, Vladimir Nabokov seems to have learned to read English poetry before he could read Russian, his native language, though he soon spoke all three languages. At age eleven, Nabokov translated Mayne Reid's "The Headless Horseman" from English to French. Moreover, as A. Pavlenko notices, while Nabokov indeed repeated many a time the sentence quoted by Pinker, if one looks at the context in which it was uttered, it becomes clear that this author with incredibly high and rigorous standards referred to ways in which spontaneous speech never measures up to the poetic excellence of written speech, and not to his own inability to speak extemporaneously [5, p. 327].

Conclusions. For bilingual writers bilingualism means more than being bilingual, being able to use two languages. They write in their second language for various reasons and to serve various purposes; bilingualism carries different meanings for them. No doubt, any future discussion of writers who achieved prominence by writing in their L 2 could not be limited to the few literary figures of the past such as Nabokov, Conrad, Triolet. At present, contemporary literature abounds in writers who, like Salman Rushdie, Victor Hernandez Cruz, or Andrei Codrescu, refuse to uphold linguistic and cultural borders, saluting the "disappearance of the outside". This phenomenon of literary translingualism is finally starting to attract the attention of scholars.

\section{References:}

1. Bilingualism: Beyond Basic Principles / Ed. by Jean-Marc Dewaele, Alex Housen, Li Wei. Clevedon, 2003. 233 p.

2. Federman R. A Voice within a Voice: Federman Translating / Translating Federman. URL: http://www.federman.com/rfsrcr2.htm.

3. Hokenson J. W., Munson M. The Bilingual Text. History and Theory of Literary Self-Translation. Manchester; N. Y. : St. Jerome Publishing, 2007. 236 p.

4. Li X. Souls in Exile: Identities of Bilingual Writers. Journal of Language, Identity, and Education. 2007. 6 (4). P. 259-275.

5. Pavlenko A. "In the world of the tradition I was unimagined": Negotiation of identities in cross-cultural autobiographies. The International Journal of Bilingualism. 2001. Volume 5. Number 3. P. 317-344.

6. Szirtes G. George Szirtes: what being bilingual means for my writing and identity. The Guardian. 2014. 3 May. URL: http://www.theguardian.com/education/2014/may/03/george-szirtes-bilingual-poetry-translation.

7. Wenger E. Communities of practice: Learning, meaning, and identity. Cambridge, MA: Cambridge University Press, 1998. 318 p. 


\section{Нечипоренко В. О. МОВНА ОСОБИСТІСТЬ БІЛІНГВАЛЬНОГО АВТОРА}

У статті проаналізовано проблему мовної особистості і креативності білінгвальних письменників. Аналіз мовних процесів білінгвальної особистості набуває надзвичайної актуальності, щзо спричинено зростанням ролі особистості у поширенні і поглибленні міжкультурної комунікації. Дослідження двомовності сприяє теоретичним розвідкам у межах інших дисчиилін (лінгвістика, соиіологія, психологія, неврологія, педагогіка) та дотичних галузей (дослідження виникнення мовлення у дітей, мовленнєвих процесів).

Останні десятиліття демонструють зростання інтересу науковиів до аналізу двомовної особистості. Поглиблене інтегративне вивчення феномену білінгвізму є ключовим підходом у сучасних лінгвістичних розвідках. Дослідження індивідуального (авторського) білінгвізму та аналіз мовної особистості як недостатньо описаного феномену видається важливим і актуальним. Метою статті є вивчення проблеми двомовної особистості, висвітлення взаємозв'язку між мовою й індивідуальністю.

Мова і індивідуальність - ие тісно пов'язані поняття, які вкрай важливі для розуміння мовної особистості письменника-білінгва. У статті проаналізовано такі метафори: мова як символічний ресурсі імоваякознака індивідуальності. Автор даного дослідження поділяє думкунауковиів, що вивчення мови і практика (авто)перекладу - ие не лише прочеси кодування і декодування мови. Білінгвальна практика тісно пов'язана з особистим залученням, зобов'язаннями і подоланням перешкод.

У статті висвітлено різні причини, через які письменники стають двомовними. Наведено приклади успішної письменницької і перекладаџької діяльності білінгвальних авторів. Двомовний автор - ие не просто сума двох повних чи неповних монолінгвальних особистостей, а радше унікальне специфічне лінгвістично-культурне новоутворення. Дослідження індивідуального авторського білінгвізму уможливлює безпосереднє вивчення феномену авторської мовної свідомості, аналіз авторського білінгвізму як соиіально-психолінгвістичного феномену, як маркера глибоких мовних контактів. Висвітлено перспективи подальших наукових розвідок у цуьому напрямі.

Ключові слова: білінгвальний (двомовний) автор, мова, мовна особистість, креативність, автопереклад, літературний транслінгвізм. 